Supplement to 'Philosophy' '

Royal Institute of Philosophy Supplement: 51

\title{
Logic, Thought and Language
}

\section{Edited by Anthony O'Hear}

\section{Contributors}

Bob Hale, M. G. F. Martin, Gregory McCulloch, Alan Millar, A. W. Moore,

Christopher Peacocke, R. M. Sainsbury, Gabriel M. A. Segal, Scott Sturgeon, Julia Tanney, Charles Travis, S. G. Williams, Timothy Williamson, Crispin Wright 


\section{Logic, Thought and Language}

ROYAL INSTITUTE OF PHILOSOPHY SUPPLEMENT: 51

EDITED BY

Anthony $\mathrm{O}^{\prime} \mathrm{Hear}$

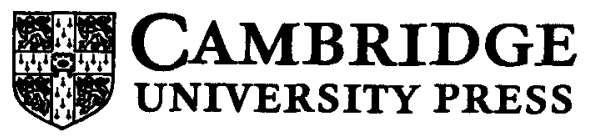


PUBLISHED BY THE PRESS SYNDICATE OF THE UNIVERSITY OF CAMBRIDGE

The Pitt Building, Trumpington Street, Cambridge, CB2 1RP, United Kingdom

CAMBRIDGE UNIVERSITY PRESS

The Edinburgh Building, Cambridge CB2 2RU, United Kingdom

40 West 20th Street, New York, NY 10011-4211, USA

477 Williamstown Road, Port Melbourne, VIC 3207, Australia

(C) The Royal Institute of Philosophy and the contributors 2002

Printed in the United Kingdom at the University Press, Cambridge Typeset by Michael Heath Ltd, Reigate, Surrey

A catalogue record for this book is available from the British Library

Library of Congress Cataloguing-in-Publication Data applied for

ISBN 0521529662 paperback

ISSN 1358-2461 


\section{Contents}

Preface v v

Notes on Contributors vi

What logic should we think with? 1

R. M. SAINSBURY

Mental Representation and Mental Presentation GREGORY MCCULLOCH

Self-knowledge, Normativity, and Construction JULIA TANNEY

The Normativity of Meaning

ALAN MILLAR

Two Theories of Names

GABRIEL M. A. SEGAL

Relativism and Classical Logic

CRISPIN WRIGHT

Principles for Possibilia

CHRISTOPHER PEACOCKE

What are these Familiar Words Doing Here?

A. W. MOORE

Particular Thoughts \& Singular Thought

M. G. F. MARTIN

Conditional Belief and the Ramsey Test SCOTT STURGEON

Necessary Existents

TIMOTHY WILLIAMSON

Ambiguity and Belief

S. G. WILLIAMS 


\section{Contents}

$\begin{array}{ll}\text { Basic Logical Knowledge } & 279\end{array}$ BOB HALE

Frege's Target $\quad 305$

CHARLES TRAVIS

$\begin{array}{ll}\text { Index } & 345\end{array}$ 